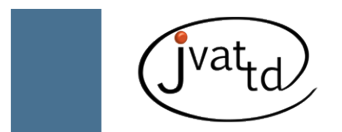

\title{
Ovine leptospirosis in Brazil
}

Lucheis SB (1), Ferreira Jr. RS (2)

(1) São Paulo Agency for Agribusiness Technology (APTA), Bauru, São Paulo State, Brazil; (2) Center for the Study of Venoms and Venomous Animals, São Paulo State University (UNESP - Univ Estadual Paulista), Botucatu, São Paulo State, Brazil.

\begin{abstract}
Leptospirosis is a zoonosis distributed worldwide, endemic mainly in humid subtropical and tropical countries, with epidemic potential. It affects a range of both wild and domestic animals, including sheep, which transport leptospires in their urine and, therefore, can infect other animals and humans who deal with them. Therefore, leptospirosis is characterized as an occupational zoonosis. In individual herds leptospirosis can cause severe economic loss due to miscarriages and outbreaks of mastitis with a significant reduction of milk production. The disease is caused by Leptospira interrogans, which was reclassified into 13 pathogenic species, and distributed into more than 260 serovars classified into 23 serogroups. The clinical signs of infection may vary depending on the serovar and host. In maintenance hosts, antibody production is generally low; there are relatively mild signs of the disease, and a prolonged carrier state with organisms in the kidneys. In incidental hosts, the disease may be more severe, with high titers of circulating antibodies and a very short or nonexistent renal carrier state. In general, young animals with renal and hepatic failure have more serious infections than adults. Several diseases may produce symptoms similar to those of leptospirosis, so that laboratory confirmation, through microscopic agglutination test, for example, is required. The effectiveness of treatment depends on early diagnosis and appropriate therapy, depending on clinical features, since leptospirosis can develop into chronic liver disease and nephropathy, progressing towards death. Improvements in habitation and sanitary conditions, rodent control, vaccination, isolation and treatment of affected animals are the main measures for the control of leptospirosis.
\end{abstract}

Key words: sheep, Leptospira, diagnosis, animal diseases.

\section{INTRODUCTION}

In recent years, the sheep industry has reappeared in southeastern Brazil, especially in São Paulo state, as an economic solution for small and medium-sized livestock breeders. This activity has attracted the attention of government officials, technicians and producers, leading to significant changes in some of its segments, including intensification of research devoted to animal production and its derivatives, increase of producer organizations and in the absorption of new technologies, resulting in improved access to credit, and especially an increase in the demand for sheep products (1).

The Brazilian sheep herd totals approximately $16,812,105$ head (2). The sheep industry has been increasing in almost the entire country, expanding to regions with no tradition of economic exploitation of these animals, which indicates that the importance of this activity and its effective participation in the agribusiness sector of the Brazilian gross domestic product (GDP) are growing (3).

An increase has been observed not only in the herds but also in the number of farms involved in 
such activity. Experts have stated that this is due to the increased demand for sheep meat, especially lamb meat, in centers of higher consumption, e.g. the metropolitan region of São Paulo city and large cities in São Paulo state, such as Campinas, Ribeirão Preto, Sorocaba, Bauru and São José do Rio Preto (4).

Since producers are concerned about the necessity of working together to make this activity feasible, the sector has become organized to make the activity competitive in the market and to obtain a high-quality product. However, inadequate sanitary actions during breeding, when added to the absence or inappropriate use of technologies, can result in low production and diseases in the herds, making the commercialization of the meat of these animals a public health risk (5).

Leptospirosis is one of the most representative zoonoticdiseases, with greateconomicimportance for livestock. This infectious disease leads to decreased dairy production, more spontaneous abortions and low fertility. Furthermore, it constitutes a serious public health problem and is related to socioeconomic characteristics, floods and occupational aspects of humans (6).

\section{HISTORY}

In 1881, in Prague, Weiss described the disease then named icterus catarrhalis, which was probably Weil's disease. In 1886, Adolf Weil made his first description of the disease, based on two observations that involved four patients and was characterized by intense jaundice, fever and hemorrhage with renal involvement. In 1883, it was recognized as an occupational disease of sewage workers (7).

The agent was first isolated in Japan in 1915 by Inada and Ito. Leptospires, denominated Spirochaeta icterohaemorrhagiae, were isolated from workers. In 1915, Uhlenhut and Fromme proved the existence of its etiological agent by inoculating into guinea pigs the blood of soldiers with suspected Weil's disease. These animals died and leptospires were microscopically identified. In 1917, Miyajima, Ido Hoki, Ito and Wani reported that rats were possible carriers of leptospires, showing that $40 \%$ of them were renal carriers (7).

In South America, leptospirosis was recognized by McDowell in 1911, who clinically diagnosed the disease during a small outbreak in Pará state, Brazil. From this clinical recognition of Weil's disease, a diagnosis was also reported in the Amazon region by Da Mata, in 1919, and in Pernambuco state by Magalhães (8).

In Brazil, the first records of leptospirosis were published in Rio de Janeiro state in 1917 by Aragão, "A presença do Spirochoeta icterohaemorrhagiae nos ratos do Rio de Janeiro" [The presence of Spirochoeta icterohaemorrhagiae in rats from Rio de Janeiro], in the journal Médico; by Bentes, "Da leptospirose de Inada ou icterus haemorrhagiae" [Leptospirosis of Inada or icterus haemorrhagiae], a thesis presented at the School of Medicine of Rio de Janeiro; and McDowell, "Do icterus epidemicus" [Icterus epidemicus], published in the journal Arquivo Brasileiro de Medicina. In 1918, Noguchi named the genus Leptospira based on the spiral shape of the bacterium (9).

In São Paulo state, Leptospira sp. in sheep was first reported by Santa Rosa and Pestana de Castro (10), with a prevalence of 34\% (dilution of 1:200 to 1:600) for prevalent Canicola and Icterohaemorrhagie serovars (11). The serum samples were also reactive against the serovars Pomona, Sejroe, Grippotyphosa, Batavie, Hyos and Australis. According to their results, dogs and rats served as the source of infection (11).

\section{ETIOLOGY AND CLASSIFICATION}

Leptospires are microorganisms that belong to the order Spirochaetales, family Leptospiraceae, genus Leptospira. Until 1989, this genus was divided only into two species, according to more or less specific serological reactions in $L$. biflexa, constituted of nonpathogenic serovars of saprophytic behavior and L. interrogans, the group containing all pathogenic serovars (12).

Taxonomic studies based on DNA analysis have resulted in the description of eight pathogenic Leptospira species: Leptospira borgpetersenii, L. inadai, L. interrogans sensu stricto, L. kirschner, L. meyeri, L. noguchii, L. santarosai and L. weilii, classified according to the antigenic composition into 25 serogroups and more than 300 pathogenic serovars (13).

At the Subcommittee on Taxonomy of Leptospiraceae Meeting held in Ecuador in 2007, L. interrogans was reclassified into 13 species of pathogenic Leptospira: L. alexanderi, L. alstonii, $L$. borgpetersenii, L. inadai, L. interrogans, L. fainei, L. kirschneri, L. licerasiae, L. noguchi, L. santarosai, L. terpstrae, L. weilii and L. wolffi, distributed 
among more than 260 serovars grouped into 23 serogroups (14).

Spirochetes are thin spiral mobile flexible unicellular gram-negative bacteria measuring 0.1 $0.3 \mu \mathrm{m}$ diameter and 6-20 $\mu \mathrm{m}$ length. The outer wall of the bacterial cell is formed by a membrane completely covered with periplasmic flagella that compose the axial filament or endoflagellum, which allows rotational and flexion-extension movements, facilitating bacterial mobility in the environment (15). They are obligate aerobes and develop relatively slowly in cultures.

Their helical cylinder (cell body) consists of nuclear material, cytoplasm, cytoplasmic membrane and a portion of peptidoglycan of the cell wall. A periplasmic flagellum is surrounded by the cylinder and is located in the periplasmic space. The end portion of each flagellum is inserted near a pole of protoplasmic cylinder firmly attached to structures denominated insertion discs. The distal point of each flagellum extends to the center of the cell and may be overlapped by flagella originating at the opposite pole $(16,17)$.

Leptospires are sensitive to desiccation, freezing, water salinity and $\mathrm{pH}$ variation. These bacteria are inactivated at any $\mathrm{pH}$ lower than 6 or higher than 8, environmental temperatures lower than $7^{\circ} \mathrm{C}$ or higher than $36^{\circ} \mathrm{C}$, humid heat $\left(121^{\circ} \mathrm{C}\right)$ for at least 15 minutes and pasteurization. They can also be inactivated by sodium hypochlorite $1 \%$, ethyl alcohol 70\%, glutaraldehyde, formaldehyde, detergent and acids (18).

\section{EPIDEMIOLOGY}

Leptospirosis is one of the zoonoses most disseminated throughout the world. It occurs in both developed and emerging countries, assuming global importance due to great outbreaks reported worldwide. Currently, it has been recognized as a reemerging infectious disease. Understanding its epidemiology is a fundamental step toward the adoption of preventive measures that would consequently decrease the risk of transmission (19).

Its incidence is significantly higher in hot (tropical) countries than in temperate regions, especially due to the prolonged survival of leptospires in hot humid environments. Furthermore, in most of the tropical developing countries humans have more opportunities to be exposed to infected animals (domestic, wild or livestock) and contaminated environments, especially during rainy periods (summer) (13, 17). Its higher occurrence is also related to the deficient sanitation found in poor regions, which allows the proliferation of domestic rodents and contact with contaminated water.

Infected animals are classified into definitive or maintenance (reservoir) hosts, to which the persistence of the enzootic cycle is attributed, or into accidental hosts, with no impact on the dissemination of this zoonosis (20). Each serovar has its preferential hosts, although a single animal species can house one or more serovars (15). The maintenance host is more susceptible to infection, since it develops chronic infection in renal tubules. Thus, urinary leptospiruria can be intermittent or continuous and presents a bacterial concentration higher than $10^{8} / \mathrm{mL}$ (21).

In rural and urban ecosystems, synanthropic rodents play the role of main reservoirs of this disease since they house Leptospira in the kidneys, eliminating them alive through the urine to the environment, which contaminates the water, soil and foods. Among domestic rodents (Rattus norvegicus, Rattus rattus and Mus musculus), $R$. norvegicus is noteworthy because it is a classic carrier of Icterohaemorrhagiae, the serovar most pathogenic to humans (22).

Transmission occurs among animals and from them to humans by direct and indirect mechanisms. Animals and humans acquire the infection from infected animals, contaminating the pasture, water and foods with urine, spontaneously aborted fetuses and uterine discharges, as well as from sexual contact, artificial insemination and viable neonates, which can house the infection for several weeks after birth (17).

The prevalence of different Leptospira serovars causing disease within a population depends on the animal reservoirs and the serovar, as well as on environmental factors, occupation and agricultural practices (13).

Serological studies in several countries showed that the Leptospira sp. infection in sheep appears to be common and is associated in most cases with the presence of the serovar Hardjo. This is the serovar most often responsible for reproductive losses in cattle and also for causing a large number of miscarriages in sheep $(23,24)$. However, other less common serovars may infect the sheep, and some authors presuppose that the sheep act as accidental hosts, becoming infected 
by serovars commonly found in other domestic and wild animals found in the region $(25,26)$.

Humans constitute accidental hosts. They can be infected by direct contact with blood, organs or tissues of infected animals or by indirect contact with contaminated water or humid soil, the main transmission routes $(13,27,28)$.

In addition to its relation to environmental and socioeconomic conditions, leptospirosis has a strong occupational feature. Azevedo et al. (29) warned about the transmission of this disease to slaughterhouse workers by the handling of organs and carcasses of infected animals. Penetration of leptospires occurs through skin or conjunctival mucosal lesions and also through intact skin after prolonged immersion in water. Inhalation of water or aerosols may result in infection through the mucosae of the respiratory system; the infection can rarely occur by animal bites (17).

In livestock, leptospires have been evidenced not only in the urine but also in semen and vaginal discharges, characterizing a reproductive disorder among animals (30). According to Corrêa and Corrêa (6), sheep can be accidental hosts of the serovar Hardjo since they acquire infection through contact with sick bovines. However, sheep with high serological titers and without contact with sick bovines can maintain leptospiruria for up to 11 months.

The occurrence of Leptospira spp. in sheep appears to be common in most countries, particularly in herds under extensive management systems, in which sheep are raised together with cattle, allowing infection via direct contact with urine or contaminated water in collective compartments $(25,31)$. The epidemiology of leptospirosis in sheep is complex and the bacterium can infect a large number of animals in the herd. However, it may become endemic for a small number of serovars, being related to those more adapted to sheep (25).

Gordon (32) and Hathaway (33) concluded that, despite presenting certain resistance to the disease status, sheep were infected by Leptospira spp. through contaminated water and pasture, especially by the serovar Hardjo, and once the infection was established the animals acted as hosts, carriers and releasers of the bacterium in the urine for more than two months.

Leptospires are found worldwide. Certain serovars, however, appear to present a limited geographic distribution. In Brazil, the ovine form of the infection was first detected by Santa Rosa and Pestana de Castro (10) in sheep from São Paulo state, $34 \%$ of which were reactive to several Leptospira spp. serovars.

In Bahia state, Brazil, serological surveys were performed by Viegas et al. (34), who found that $22.8 \%$ of sheep were reactive to the serovars Autumnalis, Castellonis, Grippotyphosa and Tarassovi. In Ribeirão Preto city, São Paulo state, Brazil, Gírio et al. (35) noted that 13 of the 30 sheep studied, at a facility of the School of Medicine, were reactive to pathogenic leptospires, 11 to the serovar Icterohaemorrhagiae and two to Pomona.

Langoni et al. (36) investigated leptospiral agglutinins in 356 sheep serum samples from different regions of São Paulo State and reported the following occurrences: Icterohaemorrhagiae (51.25\%); Castellonis (20.63\%), Hardjo (19.36\%), Bratislava (16.25\%), Andamana and Wolffi (11.88\%), Copenhageni (8.75\%), Grippotyphosa (4.34\%), Pomona (2.5\%) and Tarassovi (0.63\%).

A study carried out in Rio Grande do Sul state, Brazil, using the microscopic agglutination test (MAT) on 1,360 sheep serum samples, indicated that $466(34.26 \%)$ animals were reactive, with titers of leptospiral agglutinins ranging from 100 to 3200. The following serovars were found: Hardjo (28.4\%), Sentot (16.8\%), Hardjoprajitno (14.5\%), Fortbragg (6.3\%), Wolffi (4.7\%), Pyrogenes (1.8\%), Australis (1.6\%), Pomona (1.6\%), Sejroe (2.2\%), Castellonis (1.8\%), Hebdomadis (1.3\%), Icterohaemorrhagiae (0.5\%), Grippotyphosa (0.7\%), Canicola (0.6\%), Tarassovi (0.6\%), Bratislava (0.29\%) and Autumnalis (0.2\%), revealing that Leptospira spp. is disseminated throughout most sheep farms in the southeast and southwest mesoregions of that state (24).

Escócio et al. (37) evaluated the sanitary profile of sheep herds raised alone or together with bovines in the region of Sorocaba municipality, São Paulo state, Brazil. Among the analyzed diseases, leptospirosis presented great importance since all herds were reactive to at least one Leptospira spp. serovar. In only four herds exclusively composed of sheep, the serovar Autumnalis had the highest occurrence, followed by Pyrogenes, and in seven combined herds (sheep/bovines), the serovars Icterohaemorrhagiae, Hardjo and Javanica were the most frequent.

Cardoso et al. (38) studied the sanitary profile of goat and sheep herds in the southwest region of São Paulo state and noted that, among 100 
sheep evaluated for leptospirosis through MAT, $15 \%$ were reactive. The most frequent serovar was Icterohaemorrhagiae (26.6\%), followed by Pyrogenes, Wolffi and Hardjo (13.3\%), and Bratislava, Castellonis, Canicola and Hardjo (6.6\%).

Lilenbaum et al. (39) evaluated 13 goat herds and seven sheep flocks located in Rio de Janeiro municipality, Rio de Janeiro state, Brazil. Using MAT, 292 sheep serum samples were tested, resulting in 40 animals (13.7\%) reactive to the serovars Sejroe, Shermani, Grippothyphosa, Icterohaemorrhagiae, Autumnalis and Ballum.

Thus, in Brazil, there are few reports on leptospire isolation in naturally infected sheep. Most studies have been restricted to serological investigations (40).

\section{PATHOGENY}

The transmission of pathogenic Leptospira to sheep is apparently more common in herds that use systems management for the intensive or extensive raising of sheep along with cattle, in which sheep become infected mainly by direct contact with urine or contaminated water in the collective drinking trough. Transmission can also occur directly from the sheep by direct or indirect contact with infected urine, vaginal fluids, placenta, sexual contact or intrauterine infection $(25,26,30)$.

Though the infection may be transmitted through semen, there may also be another transmission mode, namely lambs being fed milk or colostrum from cows, leading to a clinical condition characterized by severe anemia, fever, depression and respiratory distress followed by death (41).

The microorganism penetrates the host by direct contact with infected urine or tissues, or indirectly through contaminated water or soil. The infection occurs mainly through skin injured by cuts or abrasions, or through nasopharyngeal, oral, genital or conjunctival mucous membranes. Leptospires are highly pathogenic due to the production of cytolytic enzymes, toxins and their multiplication in the endothelium of vessels (42).

After tissue invasion, leptospires rapidly diffuse to the bloodstream, actively multiplying in the interstice and in organic humors such as blood, lymph and cerebrospinal fluid (CSF), which characterizes an acute and septicemic (leptospiremia) sign, then disseminating to different organs or systems to produce different clinical manifestations (42).

Leptospiremia occurs between one and seven days of infection and ends with the appearance of circulating antibodies. Afterwards, there are migration and persistence of leptospires in the tissues, especially in the proximal renal tubules, where they can persist from weeks to years or even for the whole life in certain animal hosts. Persistence for long periods results in renal lesions, and the female genital tract represents a privileged place where the agent is protected from humoral immunity (20).

Direct consequences of primary lesions caused by leptospires are attributed to the mechanical action of the microorganism in lining endothelial cells of small vessels, which results in hemorrhages, followed by the formation of thrombi and blockage of blood supply to several organs, leading to renal tubular necrosis, hepatocellular damage, meningitis, myositis, placentitis and uveitis (21).

Lesions in the vascular endothelium can be established on account of the installation of bacteria and the period of immunity and leptospiruria due to the persistence of the microorganism at specific sites, where type-III hypersensitivity reactions occur with deposition in tissues of immune complexes formed in vivo. These mechanisms account for the renal lesion - chronic interstitial nephritis - and eye lesion - uveitis (43).

Hemorrhages, jaundice and frequent platelet deficiency occur in severe cases. Release of cytokines such as tumor necrosis factor by monocytes due to the endotoxic activity of leptospires can explain the injury to endothelial cells and the consequent hemorrhage observed in severe leptospirosis. Usually, there is mild granulocytosis and splenomegaly (44).

The subacute form of the pathogenesis is similar to the acute form but the reaction is milder. It affects all species, although it is more common in bovines and equines. The chronic form occurs in convalescent animals after the acute form and is associated with renal and hepatic damage that impairs animal growth. On the other hand, leptospires located in the reproductive tract provoke placental infection. Miscarriages, stillbirths and birth of weak animals occur in fetal acute infection and occasionally in congenital leptospirosis. After fetal expulsion, 
leptospires can be released through uterine discharges and persist in oviducts for up to 22 days after parturition (20).

In leptospirosis-induced sheep abortion, the major pathological observations correspond to a variable extent of jaundice and extensive bleeding and anemia, bloody urine and exudate. As in other animals, increased hemorrhagic petechiae are present on the kidney surface. White spots can be observed on the cortical surface, representing scarification and inflammatory cell infiltration, which can be found in subacute and chronic infections, with evidence of glomerular atrophy and tubular protein clusters. Perivascular cuffs can be observed, bleeding in the brain and vacuolization of the surfaces of endometrial cells in the uterus of sheep. The aborted fetuses produced may present bleeding, jaundice, or both, and may be highly contaminated with leptospires (26).

\section{CLINICAL SIGNS}

Since leptospirosis is a disease that follows an acute to chronic course, most cases in sheep are asymptomatic and mainly caused by a serovar adapted to the host (6). Clinical infections showing evident signs are most often caused by serovars not adapted to the hosts, but all serovars lead to changes at different levels (45).

Clinical signs are frequently related to renal and hepatic diseases or to reproductive deficiency, thus leading to an economic impact on agriculture and livestock raising, with high mortality, miscarriages, stillbirth, infertility and decreased dairy production in the herds $(13,18)$.

Leptospirosis is similar in sheep and bovines. It is characterized by fever, anorexia, intense jaundice, hemoglobinuria, anemia, nervous signs and occasionally death (46). Reproductive problems may occur, including spontaneous abortion in the final third of gestation, birth of weak lambs, stillbirth and infertility (18). In acute leptospirosis, sheep present septicemia, including fever, apathy, dyspnea, exercise intolerance, weakness and death (47).

Ellis (25) observed that this bacterium led to a systemic disease interfering with sheep reproduction and lactation and lamb survival. Most reproductive losses were directly related to the serovars Hardjo and Pomona and a small number of cases to the serovars Ballum and Grippotyphosa.
In acute infection among sheep kept for fattening, the serovar Grippotyphosa is lethal with physical deterioration in infected animals being the main cause of losses. In the chronic form, body weight loss may occur. Miscarriages have been recorded as the only clinical sign in infection by the serovar Hardjo and in the acute form by the serovar Pomona. Agalactia and oligolactia have been observed in lactating sheep whereas clinical manifestations of encephalitis are due to the presence of leptospires in sheep nervous tissue. Infection by the serovar Pomona is most frequent and constitutes the main cause of clinical leptospirosis in sheep (20).

\section{IMMUNITY AND VACCINATION}

The identification of a leptospiral serological variant is very important, since the acquired immunity is serovar specific; thus immunization protects only against homologous or antigenically similar serovars, with no cross-immunity (17). Therefore, when one or more serovars are infecting animals, the use of polyvalent vaccines is recommended (26).

The systematic use of specific bacterins against prevalent serovars in the region and the species tested has shown itself in practice to be an effective measure to control outbreaks. Vaccination produces strong immunity in animals, prevents such symptoms as miscarriage and embryonic death with absorption, and blocks the emergence of other clinical signs of disease, thus enabling control. Another benefit of vaccination is that the cost of each vaccine dose is significantly lower than that of the the antibiotic used for treatment (48). However, Leptospira sp., especially the serovar Hardjo, is an antigen of low immunogenicity that induces low-level immune responses for a short period of time (49). Thus, the fact that the immune response is low and specific for each serovar, the commercial vaccines are often an inefficient prophylactic measure (26).

Vaccination can reduce the number of renal patients and the risk of infection to handlers, especially when accompanied by educational programs in public health and hygiene in communities with the support of authorities (14). It is noteworthy that the success of immunization programs depends on ongoing epidemiological studies to monitor the occurrence of different serovars of leptospires in a given population (50). 
In Brazil, there are vaccines available, but fewer studies on anti-Leptospira vaccine in sheep than in cattle, pigs and dogs (11). Leptospirosis control in sheep using commercial vaccines is widespread but commercially available bacterins are commonly used in cattle, without, however, an assessment of the effectiveness (48).

After infection, specific antibodies appear since they are induced by opsonization of leptospires, which facilitates bacterial elimination from the host. However, the bacteria that reach the proximal renal tubules, the genital tract and the mammary glands appear to be protected from these circulating antibodies. The serum level of antibodies tends to decrease to undetectable values in animals with persistent infections (20). Anti-leptospiral immunoglobulins are present in the tubules and the bladder but do not inactivate leptospires, probably due to the absence of a complement. Leptospires do not survive in acidic urine (21).

The first serological response to infection is the production of immunoglobulin $\mathrm{M}(\operatorname{IgM})$, which rapidly increases but then diminishes to undetectable concentrations around the fourth week after infection. Within one or two weeks of infection, immunoglobulins $\mathrm{G}$ (IgG) appear and after three months constitute $80 \%$ of the antibodies detected by the MAT (48). The titer peaks between 11 and 21 days after infection, ranging from 3,200 to undetectable concentrations, and gradually decreases for approximately 11 months, but the persistence is variable (20).

Vaccination mainly induces IgG production, which has a two-week peak after the booster dose. There is, however, a rapid diminution to levels lower than those detected after natural infection. The booster dose is administered after a four-week interval. Absence of a titer does not necessarily indicate absence of humoral immune response. Vaccinated animals are protected against natural infection over several months after the antibody titer becomes undetectable by MAT (20). Therefore, seroepidemiological surveys can provide guidance as to the prevalence of serovars on the farm and the best vaccine to be utilized.

\section{DIAGNOSIS}

The laboratorial diagnosis of leptospirosis must be based on clinical and epidemiological findings associated with the results of laboratorial tests
(16). It can be complex and involves direct and indirect diagnostic tests. Indirect tests detect antileptospiral antibodies while direct ones investigate antigens or nucleic acids of leptospires in animal tissues or body fluid. The choice of the test depends on the animal species (herd or individual test) and the method available in the region (18).

In the acute phase, during the febrile period, leptospires can be found in blood, lymph, urine, semen, milk and cerebrospinal, thoracic and peritoneal fluid, as well as in fragments of organs collected during necropsy (liver, kidney, lung) and in miscarriage products, such as the fetus and placenta (9). In the attempt to visualize leptospires, direct examination techniques can be performed using dark-field microscopy, dyeing tests such as silver impregnation by Levaditi and Fontana Tribondeau and direct immunofluorescence (18). Other methods include isolation technique by culturing in Fletcher semisolid medium or isolation by inoculation in laboratory animals (hamsters or young guinea pigs). All these techniques are laborious and usually applied to individual cases or animals presenting high economic value (9).

After the initial infection, numerous leptospires are released in the urine for several weeks. Examination of a urine sample is the best opportunity to demonstrate infection in the first weeks. Then, there is a progressive decrease in the leptospires present in the urine, leading to a considerable increase in IgG and IgA antileptospiral antibody titers (20).

More recent techniques for leptospire investigation in fluid have included antigen capture ELISA or immunohistochemistry. The results obtained with these techniques increase the potential for detection of intact or fragmented leptospires since the agent is detected with the aid of specific antibodies labeled with fluorescein and enzymes such as peroxidase (7).

Saglam et al. (51) performed a study in Turkey to investigate through immunochemistry the localization of leptospires in naturally aborted sheep fetuses. One hundred and eight tissue sections (kidney, liver, lung and spleen) from aborted sheep fetuses were evaluated. The results indicated that, of 108 sheep, 19 (17\%) were positive for the presence of antigen mainly in kidney $(n=12)$, lung $(n=10)$, liver $(n=7)$ and spleen $(n=2)$, demonstrating that leptospirosis is a disease that causes miscarriage in sheep. 
Serological tests have been the most frequent methods for diagnosing leptospirosis. The MAT is considered the gold standard in its diagnosis and the reference method of the World Health Organization (WHO) (12). This method consists of using cultures of live bacteria as antigens, using representative serovars according to the regional epidemiologic data. Serological proofs hamper the interpretation of results since the determination of infectious serovars in epidemiological studies is limited because of cross-reactions $(52,53)$.

In serological diagnosis, the infecting serovar and the clinical condition must be considered. Infected animals may miscarry or become renal or genital carriers with titers lower than 100 in MAT. This occurs because serum antibody levels diminish to undetectable values in animals with persistent infections (18).

MAT detects both IgM and IgG. This technique has been used primarily to diagnose diseases caused by accidental serovars, which are not adapted to the host, or in cases of acute disease, when the serovars are adapted to the host. The test has little utility to diagnose chronic disease in maintenance hosts since the antibody response to chronic infection can be reduced or persist in subclinical infections.

Another concern is that MAT cannot distinguish post-vaccination antibody titers from titers formed after natural infection since the two can be similar. However, antibody titers formed after infection are higher and persist for a longer period relative to post-vaccination ones. Furthermore, animals vaccinated against leptospirosis may possess antibodies against serovars present in the vaccine. Therefore, the vaccination history of the tested animals must be considered. Widespread vaccination significantly contributes to the number of seropositive animals and may mask the presence of chronic infection in the herd. MAT also detects reactions by any class of immunoglobulins and a titer of 100 has been frequently accepted as the cutoff (18).

The culture of leptospires from body fluid and tissues has been recommended, but such a technique may take more than six months, is very laborious and presents a low isolation rate (54). On the other hand, the microorganism isolation from renal carriers has been very useful in epidemiological studies to establish which serovars are present in an animal species and particularly in a group of animals or in a certain geographic localization (55).

Azevedo et al. (29) investigated the isolation of leptospires from the kidneys of sheep killed in a slaughterhouse located in the city of Patos, Paraíba state, Brazil. Eighty animals without apparent clinical signs of leptospirosis were used. Leptospira spp. was isolated from four renal tissue samples by the Pasteur pipette technique, indicating sheep as possible sources of infection to which butchers are exposed, and reinforcing that leptospirosis is an occupational disease.

Silva et al. (56) performed a study in sheep slaughtered in Pelotas municipality, Rio Grande do Sul state, Brazil, and observed 4.5\% seropositivity for the serogroup Autumnalis among 44 evaluated animals. The authors identified their isolation of Leptospira noguchii as the first report of this species in Brazilian sheep, and highlighted the importance of these animals as possible reservoirs of pathogenic leptospires and their implication for public health.

To determine the occurrence of leptospirosis as infection or disease, the association between diagnostic methods has been recommended, based on the combination of serological and bacteriological proofs for isolation among other available methods such as immunohistochemistry or, more recently, proofs involving molecular biology to study the DNA of the agent (57). Polymerase chain reaction (PCR) has been used as a diagnostic method capable of detecting leptospires and other microorganisms in biological samples such as urine, cerebrospinal fluid, milk, semen and vaginal discharge $(30,39$, 58, 59).

PCR has been a diagnostic alternative due to the difficulty of rapid diagnosis and the undesirable sensitivity of serological tests at the initial stage of the disease. Such a reaction avoids the necessity for frequent handling of viable bacteria and, based on the amplification of a leptospiral DNA segment, can improve the sensitivity of diagnostic techniques at early stages of the infection/disease.

Studies performed by Lilenbaum et al. (39) confirmed PCR as a recommendable method for diagnosing sheep that carry leptospirosis by detecting the agent in the urine. In this sense, different diagnostic techniques can act jointly in epidemiological studies and significantly contribute to investigating this microorganism. 


\section{PATHOLOGIC ALTERATIONS}

In cases of acute leptospirosis, postmortem lesions show intense jaundice, submucosal and subserosal hemorrhage and hemoglobinuria. The kidneys are typically swollen, present petechiae and ecchymoses and become pale with time. The liver is also swollen and sometimes displays small necrotic foci. Ulcers and hemorrhages can be found in the abomasal mucosa. Petechiae can be found in other organs, in some severe infections. Although pulmonary edema and emphysema are rare, both have already been reported (18).

\section{TREATMENT}

Researchers have suggested that in addition to vaccination, animals should also be treated, because trying to obtain control in animals positive for leptospirosis with vaccination only runs the risk of increasing the number of animals affected, given that vaccination does not eliminate the carrier state. Streptomycin was one of the first antibiotics to be used for leptospirosis therapy and is considered today one of the best treatment options since it easily penetrates the kidneys and destroys the leptospires in renal tubules $(60,61)$. In bovines, a study conducted by Saldanha et al. (62) found that the effectiveness of streptomycin sulfate in controlling leptospirosis restored reproductive function in $92 \%$ of animals.

The main aim of the treatment is to control infection before the installation of permanent damage to the liver and kidneys. Furthermore, it aims to control leptospiruria in carrier animals, allowing their safe permanence in the group by preventing dissemination to the herd.

Intramuscular administration of the following antimicrobials can be indicated: dihydrostreptomycin $(25 \mathrm{mg} / \mathrm{kg})$ for 1 to 5 days, or oxytetracycline $(40 \mathrm{mg} / \mathrm{kg})$ and/or tylosin $(44$ $\mathrm{mg} / \mathrm{kg}$ ), once a day, for 3 to 5 days. Antimicrobial administration together with adequate diet has also been suggested as a preventive measure, namely tetracycline ( $3 \mathrm{mg} / \mathrm{kg} /$ day) for seven days (20).

The treatment efficacy may depend on the serovar involved. Fluid therapy and/or blood transfusions have been recommended as supporting treatment. For beef animals that present occasional miscarriages, vaccination and treatment of all animals with antimicrobials can be used for prevention if leptospirosis is diagnosed early. As to dairy animals, only those that are infected are treated due to the potential loss of dairy production (18).

\section{CONTROL AND PREVENTION}

Prevention is characterized by sanitary control and decrease in the risk of infection occurring due to contact with contaminated environments or infected wild animals, as well as with synanthropic animals and rodents (18).

Control measures aimed at limiting the occurrence of clinical disease are based on integrated actions in several links of the transmission chain, such as diagnosis and treatment of the infection source, the combating of synanthropic reservoirs, elimination of excessive free water, hygiene in the installations and equipment, in addition to artificial insemination and vaccination to maintain a high immunity level in the herd (16).

In herds, the disease is usually introduced by an infected animal, through the environment or by contact with other infected animals in mixed pasture. Animal reposition must be selected according to the non-reactivity of herds to leptospirosis. Animals with unknown negative serology should be kept in quarantine for four weeks and tested before being added to the herd. Vaccines against leptospirosis are available for livestock and domestic animals. Although they decrease the severity of the disease, vaccines do not prevent the infection completely because the immunity is serovar-specific and vaccines protect only against serovars included in the immunogens (18).

Therefore, the control of leptospirosis, a disease common in sheep, involves the application of the following measures: identification of sources of infection, control at the time the animals are purchased and systematic immunization with inactivated vaccines that contain regional serovars of leptospires (26). The combined use of MAT as a screening test and subsequent examination of the urine by PCR may be an appropriate strategy for identification of animals whose kidneys serve as a source of infection (38). At the time of purchase, it is necessary to verify the origin of sheep to ensure that they have a history of reproductive efficiency (11). 


\section{COPYRIGHT}

(C) CEVAP 2011

\section{SUBMISSION STATUS}

Received: May 31, 2011.

Accepted: August 24, 2011.

Abstract published online: August 25, 2011.

Full paper published online: November 30, 2011.

\section{CONFLICTS OF INTEREST}

There is no conflict.

\section{FINANCIAL SOURCE}

The State of São Paulo Research Foundation (FAPESP) provided the financial grants.

\section{CORRESPONDENCE TO}

SIMONE BALDINI LUCHEIS, Agência Paulista de Tecnologia dos Agronegócios (APTA), Av. Rodrigues Alves, 40-40, Bauru, SP, 17030-000, Brasil. Phone: +55 143203 3257. Email: silucheis@ apta.sp.gov.br.

\section{REFERENCES}

1. Carvalho RB. Potencialidades dos mercados para produtos derivados de caprinos e ovinos [Internet]. Espírito Santo do Pinhal: Capritec; 2006 [cited 2006 Dez 18]. Available from: http://www.capritec.com.br/ pdf/CAPRITEC.doc.

2. IBGE. Instituto Brasileiro de Geografia e Estatística. Produção da Pecuária Municipal - 2009 [Internet]. Available from: <htpp://www.ibge.gov.br/home/ estatística/economia/ppm/2009/ppm2009.pdf

3. Martins EC. Ovinocultura no Brasil: novas fronteiras [Internet]. [cited $2006 \mathrm{Dez}$ 19]. Available from: http://www.portaldoagronegocio.com.br/index. php? $\mathrm{p}=$ texto\&\&idT $=862$.

4. Ovinos: carne impulsiona ovinocultura no sudeste [Internet]. São Paulo: Revista Rural; 2006. [cited 2007 Jan 16]. Available from: http://www.revistarural.com. br/edicoes/2006/Artigos/rev101_ovinos_carne.htm.

5. Simplício AA, Simplício KMMG. Caprinocultura e ovinocultura de corte: desafios e oportunidades. Rev Cons Fed Med Vet. 2006;12(1):7-18.

6. Corrêa WM, Corrêa CNM. Leptospiroses. In: Corrêa WM, Corrêa CNM, editors. Enfermidades infecciosas dos mamíferos domésticos. $2^{\text {nd }}$ ed. Rio de Janeiro: Medsi; 1992. p. 219-31.

7. Gomes M. Gênero Leptospira spp. Microbiologia Clínica Veterinária VET 3225 [Internet]. Cited: October 2011. Available from: http://www6.ufrgs.br/ labacvet/files/Lepto201102.pdf.

8. Alexander AD. The distribuition of leptospirosis in Latin America. Bull World Health Organ. 1960;23(1): 113-25.

9. Brasil. Ministério da Saúde. Fundação Nacional da Saúde. Centro Nacional de Epidemiologia.
Coordenação de Controle de Zoonoses e Animais Peçonhentos. Manual de leptospirose. $2^{\text {nd }}$ ed. Brasília: Fundação Nacional de Saúde; 1999.

10. Santa Rosa CA, Pestana de Castro AF. Presença de aglutininas antileptospira em soro de ovinos e caprinos do Estado de São Paulo. Arq Inst Biol. 1963;30(16):938.

11. Melo LSS, Castro MB, Leite RC, Moreira EC, Melo CB. Principais aspectos da infecção por Leptospira sp. em ovinos. Ciênc Rural. 2010;40(5):1235-41.

12. Faine S. Guidelines for the control of leptospirosis. Geneva: World Health Organization; 1982. 171 p.

13. Bharti AR, Nally JE, Ricaldi JN, Matthias MA, Diaz MM, Lovett MA et al. Leptospirosis: a zoonotic disease of global importance. Lancet Infect Dis. 2003;3(12):757-71.

14. Adler B, de La Peña Moctezuma A. Leptospira and leptospirosis. Vet Microbiol. 2010;140(3-4):287-96.

15. Quin PJ, Carter ME, Markey B. Clinical veterinary microbiology. London: Wolfe; 1994. 648 p.

16. Badke MRT. Leptospirose. In: Encontros Técnicos Abraves; 2001. Concórdia: ABRAVES; 2001. p. 1-4.

17. Levett PN. Leptospirosis. Clin Microbiol Rev. 2001;14(1):296-326.

18. OIE - World Organization for Animal Health [homepage on the internet]. Leptospirosis. Paris: OIE; 2006 [cited 2009 Jul 6]. Available from: http://www. oie.int/eng/normes/mmanual/A_00043.htm.

19. Zavitsanou A, Babatsikou F. Leptospirosis: epidemiology and preventive measures. Health Sci J. 2008;2(2):75-82.

20. Radostits OM, Gay CC, Blood DC, Hinchcliff KW. Clínica veterinária: um tratado de doenças dos bovinos, ovinos, suínos, caprinos e eqüinos. $9^{\text {th }} \mathrm{ed}$. Rio de Janeiro: Guanabara Koogan; 2007. p. 874-87.

21. Figueiredo AO. Leptospirose bovina: prevalência, variáveis de risco e sorovares predominantes em rebanhos de Mato Grosso do Sul, Brasil [master's thesis]. Campo Grande: Universidade Federal de Mato Grosso do Sul; 2007. 77 p.

22. Shimabukuro FH, Domingues PF, Langoni H, da Silva AV, Pinheiro JP, Padovani CR. Pesquisa de suínos portadores renais de leptospiras pelo isolamento microbiano e reação em cadeia pela polimerase em amostras de rins de animais sorologicamente positivos e negativos para leptospirose. Braz J Vet Res Anim Sci. 2003;40(1):243-53.

23. Ciceroni L, Lombardo D, Pinto A, Ciarrocchi S, Simeoni J. Prevalence of antibodies to Leptospira serovars in sheep and goats in Alto Adige-South Tyrol. J Vet Med B Infect Dis Vet Public Health. 2000;47(3):217-23.

24. Herrmann GP, Lage AP, Moreira EC, Haddad JPA, Resende JR, Rodrigues RO, et al. Soroprevalência de aglutininas anti-Leptospira spp. em ovinos nas mesorregiões sudeste e sudoeste do Estado do Rio Grande do Sul, Brasil. Ciênc Rural. 2004;34(2):443-8.

25. Ellis WA. Leptospirosis as a cause of reproductive failure. Vet Clin North Am Food Anim Pract. 1994;10(3):463-78.

26. Faine S, Adler B, Bolin C, Perolat P. Leptospira and 
leptospirosis. $2^{\text {nd }}$ ed. Melbourne: MediSci; 1999. 272 p.

27. Avelar KES, Pereira MM. Espiroquetídeos. In: Trabulsi LR, Alterthum F. Microbiologia. $4^{\text {th }}$ ed. São Paulo: Atheneu; 2004. p. 399-408.

28. Bharadwaj R. Leptospirosis - a reemerging disease? Indian J Med Res. 2004;120(1):136-8.

29. Azevedo SS, Alves CJ, Andrade JSL, Santos JA, Freitas TD, Batista CSA. Isolation of Leptospira spp. from kidneys of sheep at slaughter. Arq Inst Biol. 2004;71(3):383-5.

30. Lilenbaum W, Varges R, Brandão FZ, Cortez A, de Souza SO, Brandão PE, et al. Detection of Leptospira spp. in semen and vaginal fluids of goats and sheep by polymerase chain reaction. Theriogenology. 2008;69(7):837-42.

31. Ellis WA, Bryson DG, Neill SD, McParland PJ, Malone FE. Possible involvement of leptospires in abortion, stilbirths and neonatal deaths in sheep. Vet Rec. 1983;112(13):291-3.

32. Gordon LM. Isolation of Leptospira interrogans serovar Hardjoprajitmo from sheep. Aust Vet J. 1980;56(7):348-9.

33. Hathaway SC. Leptospirosis in New Zealand: an ecological view. New Zeland Vet J. 1981;29(7):109-12.

34. Viegas EA, Viegas SARA, Caldas EM. Aglutininas anti-Leptospira em hemo-soro de caprinos e ovinos, no estado da Bahia. Arq Esc Med Univ Fed Bahia. 1980;5(1):20-34.

35. Gírio RJS, Pontes RJS, Capuano DA, Laus JE. Evidência sorológica de infecçao leptospírica em animais de biotério. Ciênc Vet. 1989;3(1):8.

36. Langoni $\mathrm{H}$, Marinho M, Baldini S, Silva AV, Cabral KG, Silva ED. Pesquisa de aglutininas antileptospíricas em soros de ovinos no Estado de São Paulo, Brasil, utilizando as provas de macroaglutinaçao em placa e soroaglutinaçao microscópica. Rev Bras Med Vet. 1995;17(6):264-8.

37. Escócio CF, Genovez ME, Castro V, Paulin LMS, Piatti RM, Okuda LH, et al. Perfil sanitário de rebanhos ovinos criados exclusivamente ou consorciados com bovinos na região de Sorocaba - São Paulo [Internet]. $35^{\circ}$ Congresso Brasileiro de Medicina Veterinária; 2008 Out 19 - 22; Gramado, RS. Gramado: CONBRAVET; 2008. [cited 2099 Mai 12]. Available from: http://www. soreges.com.br/combravet2008/anais/cd/resumos/ R0693-2.pdf.

38. Cardoso MV, Lara MCCSH, Chiebao D, Gabriel FHL, Villalobos EMC, Paulin LM, et al. Determinação da condição sanitária de rebanhos caprinos e ovinos na região sudoeste do Estado de São Paulo, Brasil [Internet]. $35^{\circ}$ Congresso Brasileiro de Medicina Veterinária; 2008 Out 19 - 22; Gramado, RS. Gramado: CONBRAVET; 20081. [cited 2009 Mai 12]. Available from: http://www.sovergs.com.br/conbravet2008/ anais/cd/resumos/R0611-2.pdf.

39. Lilenbaum W, Varges R, Ristow P, Cortez A, Souza SO, Richtzenhain LJ, et al. Identification of Leptospira spp. carriers among seroreactive goats and sheep by polymerase chain reaction. Res Vet Sci. 2009;87(1):169.

40. Freitas JC, Silva FG, Oliveira RC, Delbem ACB, Müller
EE, Alves LA, et al. Isolation of Leptospira spp. from dogs, bovine and swine naturally infect. Ciênc Rural. 2004;34(3):853-6.

41. Simpson VR, Done S. Leptospira hardjo and lambs received cows colostrum. Vet Rec. 1989;124(17):469.

42. Zunino EM, Rolando PP. Leptospirosis: puesta al día. Leptospirosis: a literature review. Rev Chil Infectol. 2007;24(3):220-6.

43. Monahan AM, Callanan JJ, Nally JE. Host-pathogen interactions in the kidney during chronic leptospirosis. Vet Pathol. 2009;46(5):792-9.

44. Higgins R. A minireview of the pathogenesis of acute leptospirosis. Can Vet J. 1981;22(1):277-8.

45. Lefebvre RB. Leptospiras. In: Hirsh DC, Zee YC. Microbiologia veterinária. Rio de Janeiro: Guanabara Koogan; 2003. p. 174-8.

46. Pugh DG. Clínica de ovinos e caprinos. São Paulo: Rocca; 2004. 203-4 p.

47. Cebra C, Cebra M. Enfermidades dos sistemas hematológico, imunológico e linfático (doenças multissistêmicas) In: Pugh DG. Clínica de ovinos e caprinos. São Paulo: Rocca; 2004. 420 p.

48. Herrmann GP. Leptospira sp. em ovinos do Rio Grande do Sul: soroprevalência e avaliaçao da imunogenicidade da bacterina [master's thesis]. Belo Horizonte: Universidade Federal de Minas Gerais; 2002. $41 \mathrm{p}$.

49. Bolin CA, Cassels JA, Hill HT, Frantz JC, Nielsen JN. Reproduction failure associated with Leptospira interrogans serovar Bratislava infection of swine. J Vet Diag Invest. 1991;3(1):152-4.

50. Wang Z, Jin L, Wegrzyn A. Leptospirosis vaccines. Microb Cell Fact. 2007;6(1):39.

51. Saglam YS, Yener Z, Temur A, Yalcin E. Immunohistochemical detection of leptospiral antigens in cases of naturally occurring abortions in sheep. Small Rumin Res. 2008;74(1):119-22.

52. Galton MM, Sulzer CR, Santarosa CA, Fields MJ. Application of a microtechnique to the agglutination test for leptospiral antibodies. Appl Microbiol. 1965;13(1):81-5.

53. Cole JR Jr, Sulzer CR, Purssell AR. Improved microtechnique for the leptospiral microscopic agglutination test. Appl Microbiol. 1973;25(6):976-80.

54. Oliveira SJ. Atualização nos conceitos sobre leptospirose em suínos. Hora Vet. 1994;79(1):52-5.

55. Ellis WA. Leptospirosis in pig. Pig Vet J. 1992;28(1):2434.

56. Silva EF, Brod CS, Cerqueira GM, Bourscheidt D, Seyffert N, Queiroz A, et al. Isolation of Leptospira noguchii from sheep. Vet Microbiol. 2007;121(12):144-9.

57. Larsson CE, Yasuda PH, Santa Rosa CA. Leptospirose suína. Inquérito sorológico e bacteriológico em municípios dos estados de São Paulo, do Paraná e de Santa Catarina. Rev Fac Med Vet Zootec Univ São Paulo. 1984;21(1):43-50.

58. Mérien F, Amouriaux P, Perolat P, Baranton G, Sanint Girons T. Polymerase chain reaction of Leptospira spp. in clinical samples. J Clin Microbiol. 1992;30(9):221924. 
59. Balakrishnan G, Govindarajan R, Roy P, Gopu P, Jayakumar V, Manohar BM. Diagnosis of leptospiral mastitis in a cow by polymerase chain reaction. Tamilnadu J Vet Anim Sci. 2009;5(2):75-6.

60. Gírio TMS, Magajevski FS, Gírio RJS, Miashyro S, Rodrigues LH, Scarcelli EP, et al. Uso de estreptomicina na eliminação da leptospirúria em touros (Bos taurus indicus) naturalmente infectados pelo sorovar Hardjo. Arq Inst Biol. 2005;72(2):161-70.
61. Gerritsen MJ, Koopmans MJ, Dekker TC, De Jong MC, Moerman A, Olyhoek T. Effective treatment with dihydroestreptomycin of naturally infected cows shedding Leptospira interrogans serovar Hardjo subtype Hardjobovis. Am J Vet Res. 1994;55(3):339-43.

62. Saldanha GB, Cavazini NC, Silva AS, Fernandes MB, Badke MRT, Pivetta CG. Sorologia positiva para Leptospira butembo em bovinos apresentando problemas reprodutivos. Ciênc Rural.2007;37(4):11824. 